\title{
Small-scale variability of physical properties and structural characteristics of Antarctic fast ice
}

\author{
A. L. VeAzEY, M. O. JefFries AND K. MORRIS \\ Geophysical Institute, University of Alaska-Fairbanks, Fairbanks, AK 99775-0800, U.S.A.
}

\begin{abstract}
The small-scale variability of physical properties and structural characteristics of multiple pairs of fast-ice cores obtained during the austral summer of 199192 at two Antarctic sites, McMurdo Sound (MCM) and Pine Island Bay (PIB), are examined and discussed with respect to the growth and decay of the sea ice. The ice at the MCM site was thicker than that at the PIB site and was covered by a somewhat thinner snowpack. While mean salinity and emperature of the ice at the two sitcs were similar, small-scale variations in both salinity and tempcrature were greater at PIB than at MCM. The ice sheet at MCM was a two-layer medium consisting of congelation ice overlying platelet ice. The ice from the PIB site, however, was composed of mainly frazil ice and layers of congelation ice with occasional thin layers of snow-ice at the surface of the cores. Crystal sub-structure measurements, $c$ axis orientation and brine-layer spacing from the MCM cores revealed that the congelation ice had moderately aligned, horizontally oriented $c$ axes, suggesting that cast-west currents off the southwest tip of Hut Point Peninsula control crystal-growth orientation.d others: Variability of physical and structural characteristics of Antarctic fast ice
\end{abstract}

\section{INTRODUCTION}

The Antarctic sea-ice cover annually retreats from a maximum area of $20 \times 10^{6} \mathrm{~km}^{2}$ in September to a minimum of $4 \times 10^{6} \mathrm{~km}^{2}$ in February (Zwally and others, 1983). Consequently, there are significant annual variations in water, salt and heat fluxes, as well as oceanic biological processes in the Southern Ocean. While largescale global studies using satellite and ground data provide an important tool for defining the mechanisms which control the areal extent of sea ice on an annual basis, small-scale studics are important for better understanding the processes responsible for the growth and decay of sea ice and interpreting satellite data.

The majority of small-scale studies of sea-ice properties have focused on salinity variations in Arctic sea ice (e.g. Weeks and Lee, 1958, 1962; Cox and Weeks, 1974; Tucker and others, 1984). Apart from studies by Eicken and others (1991), which described the spatial variability of ice texture, salinity, chlorophyll $a$ and nutrients from floes in the Weddell Sea, and Danielson and Jeffries (1992), who have reported on variations of physical properties and structural characteristics of a single floe from the western Ross Sea, there have been few Antarctic investigations of small-scale sea-ice properties and structure.

This study presents the results of an investigation of two Antarctic fast-ice sites, one in the Ross Sea and the other in the Amundsen Sea. Analysis of snow depth, ice thickness, salinity, temperature and crystal structure from both sites, as well as c-axis orientation and plate width from MCM, provide the means with which to investigate the small-scale horizontal and vertical variations between corcs as well as the differences in growth histories and conditions between sites.

\section{STUDY AREA AND METHODS}

The two fast-ice sites selected for this study, one located in the southwestern Ross Sea and the other in the southeastern Amundsen Sea, were visited during a cruise aboard USCGC Polar Sea in the austral summer of 1991 92. Ice samples from the Ross Sca were obtained on 9 January 1992 from fast ice located southwest of the tip of Hut Point Peninsula in McMurdo Sound (Fig. 1). On 4 March 1992, ice samples from the Amundscn Sea wore obtained in Pine Island Bay (Fig. 1). At the time the ice was sampled, mean air temperature and wind speed were $5.5^{\circ} \mathrm{C}$ and $1.6 \mathrm{~ms}^{1}$ at McMurdo Sound (MCM) and $-11.3^{\circ} \mathrm{C}$ and $11.4 \mathrm{~ms}^{-1}$ at Pine Island Bay (PIB).

Upon arrival at each site, a $30 \mathrm{~m}$, east-west oricnted transect was marked in the snow overlying the fast ice. Snow-depth and ice-thickness measurements were made at $1 \mathrm{~m}$ intervals along each transect. Pairs of $100 \mathrm{~mm}$ diameter ice cores were drilled at the 0, 1, 5, 15 and $30 \mathrm{~m}$ marks. The orientation of the corcs was marked and maintained after removal from the ice sheet. The first of each pair of cores was used to obtain temperature and salinity data. Temperature measurements were made by inserting a thermistor probe attached to a digital thermometer into the ice at $0.1 \mathrm{~m}$ intervals along the length of the core. The core was then cut into $0.1 \mathrm{~m}$ 


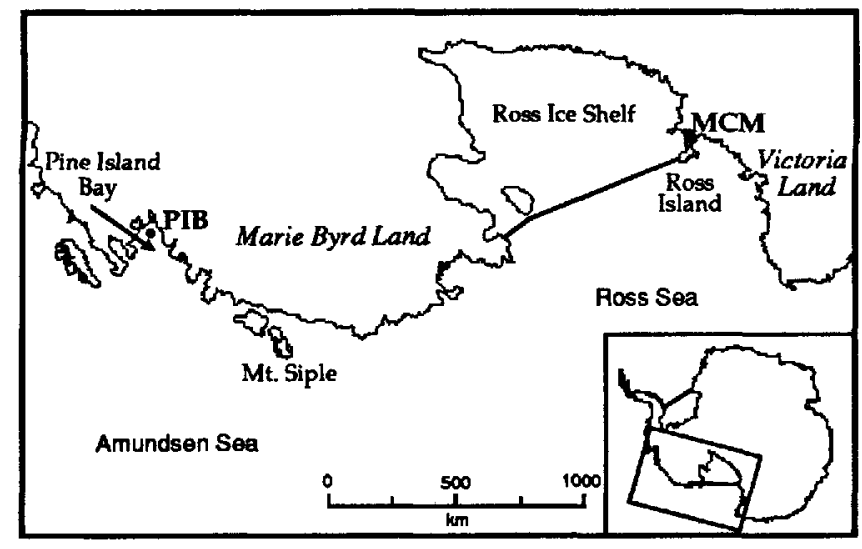

Fig. 1. Map of the eastern Pacific sector of the Southern Ocean showing the location of the two fast-ice sites: McMurdo Sound (MCM), $77^{\circ} 52.634^{\prime} S, 166^{\circ} 45.781^{\prime} E$ and Pine Island Bay (PIB), $74^{\circ} 38.157^{\prime} \mathrm{S}, 102^{\circ}$ $17.715^{\prime} \mathrm{W}$. The insert map shows the general location of the study area.

sections, returned to the laboratory and melted prior to taking salinity measurements using a Beckman Solubridge.

The second core of each pair was packaged and shipped to the laboratory for stratigraphic and structural analyses. Each core was split longitudinally and vertical thick sections approximately $5 \mathrm{~mm}$ thick were cut and viewed between cross-polarized filters in order to determinc crystal structure and plot stratigraphic profiles. Vertical and horizontal thin sections, approx-imately $1 \mathrm{~mm}$ thick, of representative crystal structures, were prepared and photographed. In addition, c-axis orientations from horizontal thin sections cut at $0.2 \mathrm{~m}$ intervals from the east-west oricnted MCM cores were measured on a Rigsby stage. Digital video images of the McMurdo Sound sections were recorded using a CCD camera mounted on a microscope and attached to a Macintosh computer. Platc-width (brine-layer spacing) data were compiled from measurements made directly on the video images.

\section{RESULTS}

\section{Snow depth and ice thickness}

The mean snow depth (土standard deviation) at PIB, $0.27 \pm 0.04 \mathrm{~m}$, was deeper than that at MCM, $0.18 \pm 0.03 \mathrm{~m}$, while the ice at MCM was thicker, $1.76 \pm 0.02 \mathrm{~m}$, than the ice at PIB, $1.49 \pm 0.10 \mathrm{~m}$ (Table 1). Gencrally, thick snow was found covering thin ice and vice versa (Fig. 2). The variability of snow depths between the two sites was similar (Table 1).

The mean snow-depth values at both sites fell close to previously recorded Antarctic snow-depth valucs of $0.34 \pm 0.15 \mathrm{~m}$ in the Bellingshausen Sea (Jeffries and others, 1994a), $0.080 .59 \mathrm{~m}$ in the Weddell Sea (I ange and Eicken, 1991), $0.160 \pm 0.034 \mathrm{~m}$ in the western Ross Sea Danielson and Jeffrics, 1992) and $0.020 .6 \mathrm{~m}$ in McMurdo Sound (Paige and Lee, 1967). The snow covers at PIB and MGM were significantly less than those recently observed in the castcrn Ross and Amundsen Seas, which averaged $1.50 \pm 0.49 \mathrm{~m}$ (Jeffries and others, 1994b).
Table 1. A summary of mean and standard deviation for snows depth, ice thickness, temperature, salinity and percentage of ice type for $M C M$ and PIB. Numbers in parentheses are the number of measurements

$$
M C M
$$

\section{$P I B$}

\begin{tabular}{|c|c|c|}
\hline Snow depth (m) & $0.18 \pm 0.03(50)$ & $0.27 \pm 0.04(31)$ \\
\hline Ice thickness (m) & $1.76 \pm 0.02(31)$ & $1.49 \pm 0.10(31)$ \\
\hline \multicolumn{3}{|l|}{ Ice temperature } \\
\hline$\left({ }^{\circ} \mathrm{C}\right)$ & $-2.8 \pm 0.4^{\circ}(89)$ & $-2.8 \pm 1.7^{\circ}(73)$ \\
\hline Ice salinity (\%o) & $5.3 \pm 0.8$ & $5.0 \pm 2.2$ \\
\hline \multicolumn{3}{|l|}{ Ice types $(\%)$} \\
\hline Snow-ice & 0 & $2.4 \pm 1.8$ \\
\hline Frazil & 0 & $79.0 \pm 7.8$ \\
\hline Congelation & $54.4 \pm 4.8$ & $16.0 \pm 9.2$ \\
\hline $\begin{array}{c}\text { Congelation/ } \\
\text { platelet }\end{array}$ & $\pm 3.0 \quad(5)$ & 0 \\
\hline Platelet & $38.8 \pm 2.4$ & $1.4 \pm 3.1$ \\
\hline
\end{tabular}

Ice-thickness measurements from McMurdo Sound made in previous years, at approximately the same time of year as this study, had similar values. Jeffries and Weeks (1991a) reported a mean ice thickness of $1.94 \mathrm{~m}$ and Leventer and others (1987) measured fast-ice thicknesses ranging from 1.5 to $2.0 \mathrm{~m}$. No previous icethickness data are available from Pine Island Bay. Although the ice there was thinner than it was in McMurdo Sound, this may have been a result of the difference in sampling dates, with PIB measurements made nearly 2 months after those at MCM, allowing for greater basal melt of the ice at PIB prior to sampling. Icethickness measurements were more variable at PIB than at MCM (Table 1).

\section{Salinity}

The MCM samples had a slightly higher mean salinity $(5.3 \pm 0.8 \%$ ) than those from PIB $(5.0 \pm 2.2 \%$ ) (Table 1). Previous studies during the austral summer reported mean salinities from McMurdo Sound fast ice of $4.21 \%$

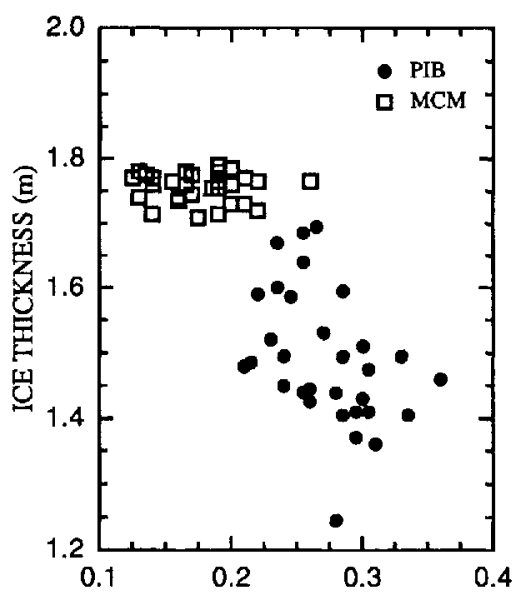

Fig. 2. Scatter plot of snow depth us ice thickness at MCM and PIB. 
Jeffries and Weeks, 1991 a) and mean pack-ice salinities from the western Ross Sea of $4.5 \%$ Jeffries and Weeks, 1991b), both of which are lower than the 5.3\% measured during this field season. Individual cores from McMurdo Sound fast ice, however, had mean salinities with a range between 2.95 and 5.39\% (Jeffries and Weeks, 1991b), which spans the present results. (Kow and others (1982) calculated an overall mean salinity of $6 \%$ from first-year ice samples in McMurdo Sound during October and November, while a mean salinity of $4.6 \%$ with a range between $1.9 \pm 1.0$ and $6.4 \pm 2.0 \%$ was obtained from Weddell Sea samples obtained in February and March.

Composite salinity profiles from MCM and PIB are considerably different (Figs 3 and 4). In the MCM cores, a minimum salinity at the surface increases in value down to $0.3 \mathrm{~m}$, whereupon it remains fairly constant with depth with only minor fluctuations to the base of the core. On the other hand, salinity values at $\mathrm{PIB}$ have a moderate surfacc salinity and a strong sub-surface maximum at $0.5 \mathrm{~m}$; from there, salinity decreases significantly with depth to the base of the corc. Salinity values within the PIB cores show greater variations, both vertically and horizontally, than those within the MCM cores (Figs 3 and 4) with salinity measurements ranging from 2.60 to $6.95 \%$ at MCM and from 0.75 to $12.3 \%$ at PIB.

\section{Temperature}

The overall mcan ice tempcrature at MCM $(-2.8 \pm$ $\left.0.38^{\circ} \mathrm{C}\right)$ was the same as that at PIB $\left(-2.8 \pm 1.74^{\circ} \mathrm{C}\right)$, yet PIB temperatures showed a much greater variation Table 1). While individual MCM temper-atures ranged from $3.3^{\circ}$ to $-1.9^{\circ} \mathrm{C}$, $\mathrm{PIB}$ temperatures had a much wider range, between $-9.4^{\circ}$ and $-1.4^{\circ} \mathrm{C}$. The icc sampled from McMurdo Sound is typical of annual summer ice in the Ross Sea, which is identified by warm, nearly isothermal temperatures (Paige, 1966; Jelfries and Weeks, 1991a, b; Danielson and Jeffries, 1992). Addit-ional cores drilled during this cruise from pack ice in the Amundsen and Bellingshausen Seas have temperature profiles similar to $\mathrm{MCM}$ with mean temperatures which range from $-2.2^{\circ}$ to $-0.2^{\circ} \mathrm{C}$ and show littlc variation with depth.

The composite core profiles illustrate the significant difference between the thermal characteristics of the ice at MCM and PIB (Figs 3 and 4). The MCM profile displays a slight $\mathrm{C}$-shaped curve with maximum temperatures of $-2.6^{\circ} \mathrm{C}$ near the surface and $-1.9^{\circ} \mathrm{C}$ at the base of the ice and a minimum of $-3.1^{\circ} \mathrm{C}$ at a depth of $1.0 \mathrm{~m}$. Both horizontal as well as vertical variations in temperature are small and the composite profile appears nearly isothermal. On the other hand, PIB temperatures increase from $-7.1^{\circ}$ to $-2.6^{\circ} \mathrm{C}$ between the surface and $0.5 \mathrm{~m}$ depth, and remain nearly isothermal with only a moderate increase to $-1.7^{\circ} \mathrm{C}$ near the base of the ice. Ice temperatures near the top of the core show the most significant horizontal variations, while ice temperatures near the base change very little over distance.

\section{Stratigraphy}

Stratigraphic profiles reveal large differences in crystal structure between the two sites (Fig. 5). The ice sheet at MCM is predominantly a two-layered medium with an
TEMPERATURE $\left({ }^{\circ} \mathrm{C}\right)$

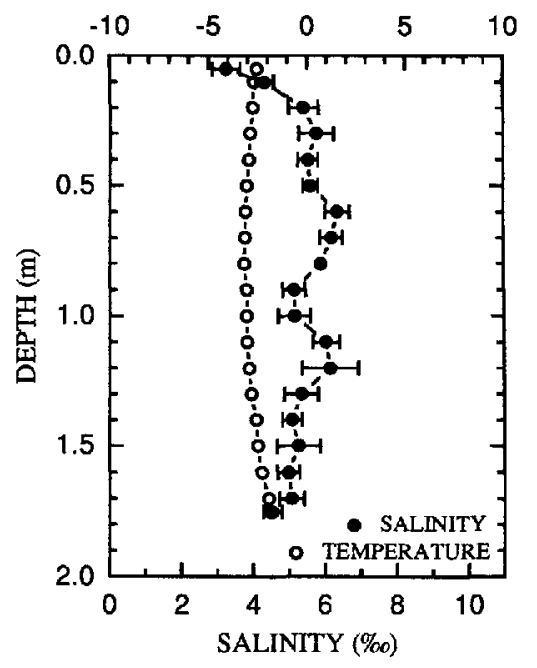

Fig. 3. Temperature and salinity profiles at MCM. Each data poinl represents the mean and standard deviation of five values each measured at the same depth in five ice cores. This applies to Figures 48.

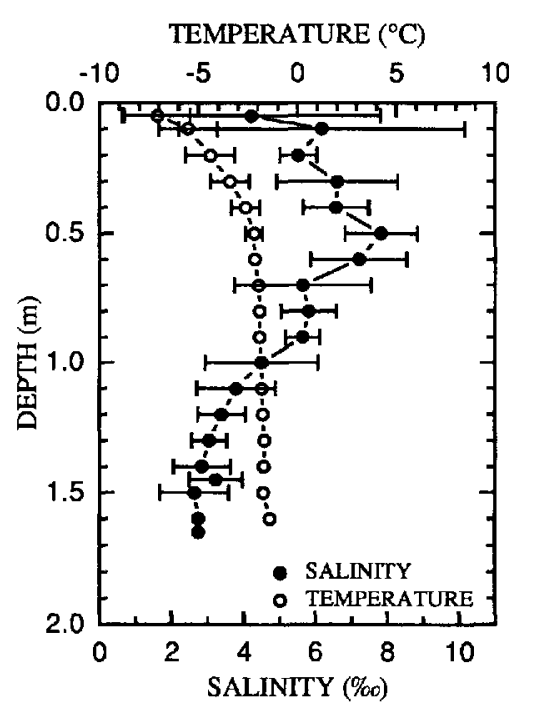

Fig. 4. Temperature and salinity profiles at PIB.

upper layer consisting of congelation ice and a lower layer of platelet icc. At the boundary between the two layers, there is a transition zone composed of a mixture of congelation and platelet ice (Jeffries and Weeks, 1991a, 1993; Jeffries and others, 1993). Mean percentage composition of each ice type for each core was calculated by dividing the total length of each ice type by the total length of each core; individual core values were then averaged for mean site composition. At the time of sampling, MCM corcs were composed of $54.4 \pm 4.8 \%$ congelation ice, $38.8 \pm 2.4 \%$ platelet ice and $6.8 \pm 3.0 \%$ transition ice, and showed little variation between cores (Table 1). This structurc-stratigraphy is similar to previous findings from McMurdo Sound Ueffries and Weeks, $1991 \mathrm{a}$; Jeffrics and othcrs, 1993).

PIB cores were composed mainly of frazil ice $(79 \pm 7.8 \%)$ with interspersed layers of congelation ice $(16.0 \pm 9.2 \%)$ at depth (Table 1; Fig. 5). Shallow layers 

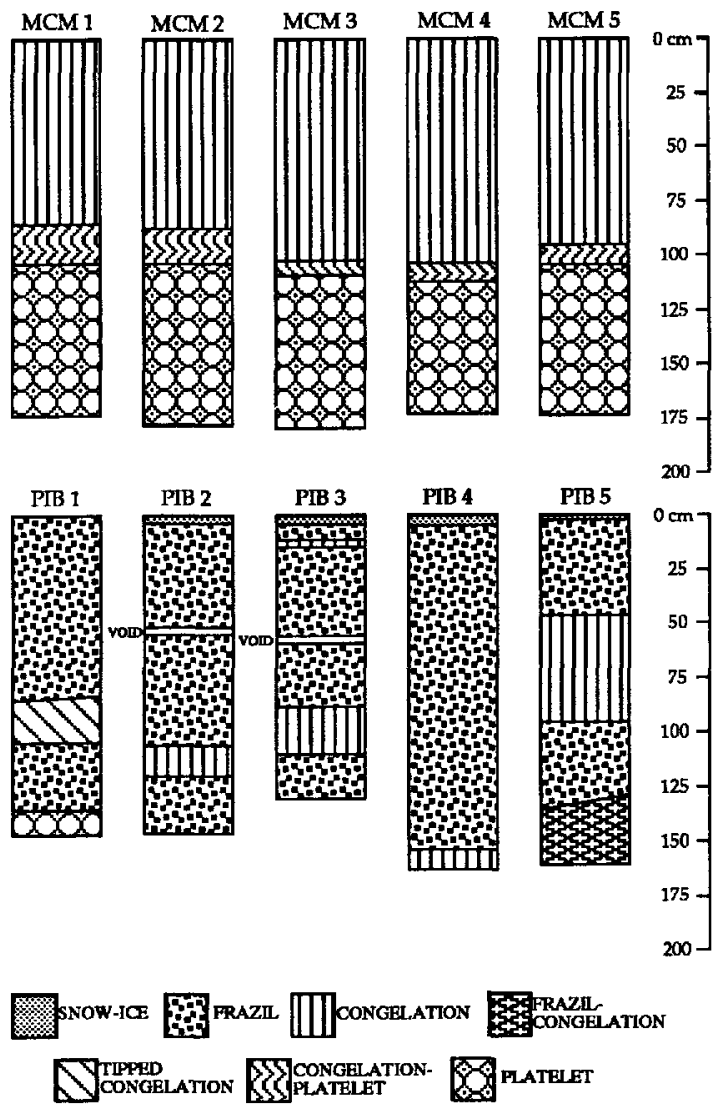

Fig. 5. Stratigraphy diagrams from $M C M$ and $P I B$ showing the variations in crystal structure.

of snow-ice at the upper surface of the corcs in PIB $2 \cdots 5$ $(2.4 \pm 0.8 \%)$ and a layer of platelet ice at depth in PIB were also present. In addition, there were two voids at depth in cores PIB 2 and 3, which werc determined by the distance the barrel of the ice core dropped through the icc during coring. Ice types and their relative locations within the ice shcet vary considerably between the cores from PIB, unlike those from MCM.

Tipped congelation-ice layers and large amounts of frazil ice in the PIB cores stggest a turbulent environment during ice formation. These characteristics contrast with the consistent bi-layer structure and the regular, downward growth and vertical, columnar texture of congelation crystals in the MCM cores. The large amounts of frazil ice, evidence of deformation events and multiple-ice types in the PIB cores, are similar in stratigraphic composition to cores obtained in the Amundsen and Bellingshausen Seas pack ice during the 1992 cruise (Jeffrics and others, 1994b), which consisted mainly of frazil ice and numerous fcatures indicative of deformation. These differences illustrate the wide range of physical conditions affecting the growth environment of sca ice around the Antarctic contincnt.

\section{Crystal sub-structure}

Crystal sub-structure measurcments of $c$-axis orientation and plate width were performed on MCM congelationice crystals at $0.2 \mathrm{~m}$ intervals (Fig. 6). $c$-axis orientation shifted from $115 \pm 25^{\circ}$ to $66 \pm 19^{\circ}$ between depths of 0.2 and $0.4 \mathrm{~m}$. Between 0.4 and $1.0 \mathrm{~m}$, the orientation remained fairly constant, ranging from $66 \pm 19^{\circ}$ to
$87 \pm 19^{\circ}$. The roughly east-west orientation is close to values obtaincd by Gow and others (1982) in approximately the same location. Measurements at 1.2 and $1.4 \mathrm{~m}$ showed the largest variations with mean values of $93 \pm 60^{\circ}$ and $56 \pm 56^{\circ}$, respectively. These values occur where platelet ice begins to dominate the stratigraphic profiles (Fig. 5). Bclow $1.0 \mathrm{~m}$, c-axis orientation changes rapidly with each successive depth interval.

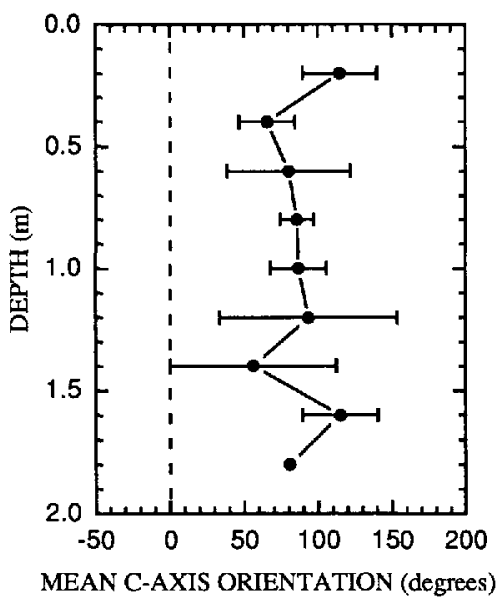

Fig. 6. Mean c-axis orienlation profile from MCM.

$c$-axis orientation standard-deviation $\left(s_{0}\right)$ profiles for each core (Fig. 7) show standard deviations ranging from $13^{\circ}$ to $67^{\circ}$. Similar values were reported by Jeffries and Weeks (1993) in the western Ross Sea and by Weeks and Gow (1978, 1980) along the northern coast of Alaska. Crystal alignment, strongest at $1.0 \mathrm{~m}$ as illustrated by the low $s_{0}$ values, decreases from $1.0 \mathrm{~m}$ toward both the surfacc and the basc of the ice. Previous studies by Jeffries and Weeks (1993) and Jeffries and others (1993) present a similar range of $s_{0}$ values, but the profiles varicd from site to site and do not display the roughly C-shaped curve apparent in these data.

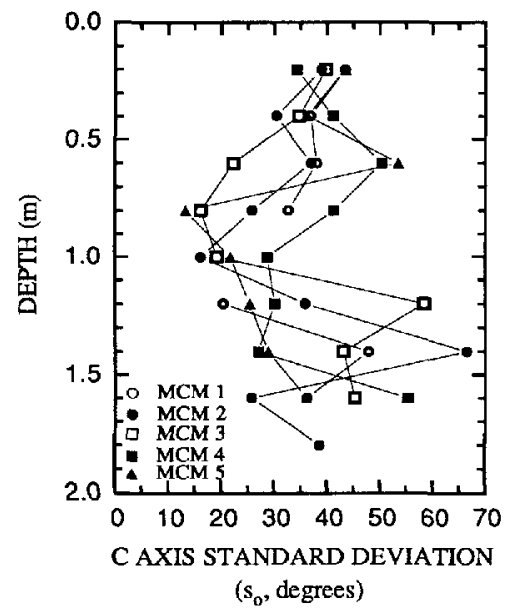

Fig. 7. Profile of the variations in congelation ice $s_{0}$ zalues (c-axis standard deviation) for sites MCM 1-5.

The mean plate width $\left(a_{0}\right)$ of the congelation ice at MCM varied between $0.84 \pm 0.23$ and $1.01 \pm 0.36 \mathrm{~mm}$, slightly higher than the range $(0.490 .99 \mathrm{~mm})$ reported 
by Jeffries and others (1993). There is a general trend toward increasing plate width from the surface down to $1.2 \mathrm{~m}$ with $a_{0}$ increasing from $0.84 \pm 0.23$ to $1.01 \pm 0.36 \mathrm{~mm}$ (Fig. 8). Below $1.0 \mathrm{~m}$ are the crystals with the largest plates and they show more variation at each depth than those in the upper $1.2 \mathrm{~m}$ of the core. The MCM profile, with its somewhat irregular variations in $a_{0}$ with depth, is similar to the $a_{0}$ profile given by Jeffries and others 1993) and contrasts with the steadily increasing $a_{0}$ values reported in Paige (1966).

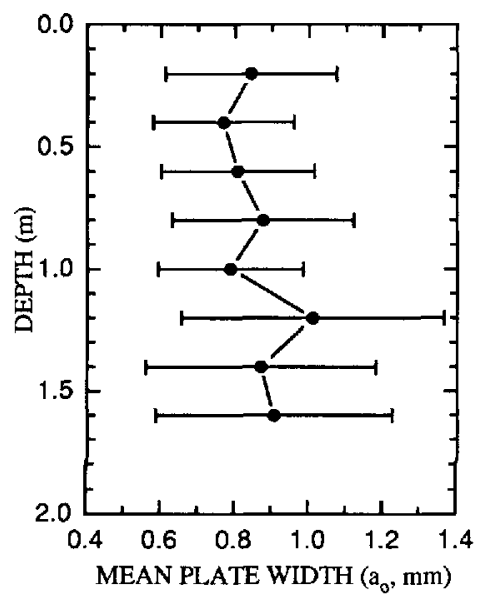

Fig. 8. Profile of mean plate widths $\left(a_{0}\right)$ at MCM.

\section{DISCUSSION}

The stratigraphy and physical properties (excluding snow depth) measured at PIB showed a significantly higher degree of variability between cores than those at MCM. The stratigraphic profiles from PIB suggest that the ice was formed in a turbulent environment and are indicative of high wind and wave action which cause frazil-ice generation, rafting and ridging events, and perhaps flooding of the snow on the ice surface, creating snowice. While the voids in the ice might indicate brine drainage prior to sampling, they might also reflect deformation events. For instance, winter storms could create jumbled piles of rafted ice with interstitial air pockets which remain unfrozen as voids within the ice cover. The PIB profiles differ from core to core, regardless of core spacing. Although these cores were drilled from fast ice in Pine Island Bay, their exact origin is uncertain. While the ice may have grown in the bay during heavy winter storms, the possibility cxists that the ice originated further offshore and was subsequently blown in to the bay where it was consolidated as fast ice.

The temperature profiles from the ice at PIB reflect a cold atmospheric environment. Reduced brightness temperatures in passive-microwave images from Pine Island Glacier (Zwally and others, 1983) may be evidence of cold, katabatic winds which would cool the ambient air and upper layers of the sca ice in Pine Island Bay. The horizontal variation in temperatures near the ice surface may be a result of fluctuating air temperatures and/or differences in the amount of snow acting as insulation from core to core. Cold air temperatures could explain the high-salinity values in the upper $0.5 \mathrm{~m}$, since brine drainage would be minimal. The heat flux from the occan has warmed the ice below $0.5 \mathrm{~m}$, resulting in significant brine drainage and lower salinities. The horizontal variations in the upper $0.2 \mathrm{~m}$ salinity values are most likely a result of snow-ice formation which would lead to lower and more variable salinity values depending on the proportions of snow and sea water in the ice.

Small-scale horizontal and vertical variations between cores at MCM were less significant than those at PIB. The two-layer stratigraphic profile defined by congelation ice overlying platelet ice has been a well-known feature of McMurdo Sound sea ice for the past three decades (Paige, 1966; Gow and others, 1982; Lewis and Perkin, 1985; Crocker and Wadhams, 1989; Jeffries and Weeks, 1991a; Jeffries and others, 1993). Stable congclation-ice growth generally begins in McMurdo Sound in April and is supplemented by later platelet-ice accretion on to the bottom laycr of the congelation-ice sheet. Ice thickness at MCM may be greater than that at PIB as a result of platelet-ice growth, less snow during the winter ice-growth period, or the earlier sampling date, and resultant minimal basal melt at MCM. Platelet ice is thought to form as lowdensity water flows northward from under the Ross Ice Shelf, becomcs supercooled through adiabatic decompression, and accretes on to the base of the sea-ice sheet in the form of large angular platelet-ice crystals (Lewis and Perkin 1985; Grocker and Wadhams, 1989). The platelet crystals are consolidated by interstitial congelation-ice growth Jeffries and others, 1993). While some previous melt had probably occurred at the basc of the ice sheet, the uniformity of the MCM stratigraphic profiles suggests that the formation of the platelet ice begins at approximately the same time over the range of the transect.

The warmer air temperatures of McMurdo Sound, as compared to Pine Island Bay, are evident in the warm surfacc temperatures of the MCM cores. The small horizontal variation in temperature suggests that similar processes are occurring over distances spanned by the $30 \mathrm{~m}$ transect at MCM. While a significant amount of brine drainage had occurred prior to sampling, the mcan salinities of both sites are still well above the mean salinity of 3\%o reported for Arctic ice of similar thickness (Cox and Weeks, 1974). Horizontal variations in salinity values at MCM are minimal when compared to those of the PIB cores. In addition, the standard deviation of $0.8 \%$ in the salinity profiles at MCM was similar to previous results in the Arctic (Weeks and Lee, 1962; Lake and Lewis, 1970; Tucker and others, 1984), but the standard deviation of $2.2 \%$ at PIB was significantly greater than previous studies. These findings again lead to the conclusion that, while similar growth and decay events may be occurring across the $30 \mathrm{~m}$ transect at MCM, processes at PIB may be significantly different across the sampling transect.

Previous research on $c$-axis orientations has confirmed that water currents can control the alignment of the crystals as they are formed at the ice--sea-water interface (Weeks and Gow, 1978; Langhorne, 1983; Nakawo and Sinha, 1984; Langhornc and Robinson, 1986). The congelation ice in the upper layers of the MCM cores supports findings by Gow and others (1982) that the current direction is generally east-west off the southwestern tip of Hut Point Peninsula. As a function of depth, $c$-axis orientation variations in the upper $1.0 \mathrm{~m}$ of the cores suggests that the current direction can change 
over time. Variations below $1.0 \mathrm{~m}$ may be a result of the effect of loose conglomerations of platelet-ice crystals creating a slower and more chaotic flow of water at the ice-water interface. The general trend of increasing $a_{0}$ values with depth in the upper $1.0 \mathrm{~m}$ may be attributed to a decrease in the growth rate with depth, as explained by Lofgren and Weeks (1969) and Nakawo and Sinha (1984). The largest horizontal variations in $a_{0}$, found near the basc of the cores, are probably due to the effects of platelet ice on water flow. At some locations, the platelet ice appears to enhance the flow rate in the favored direction of crystal growth, parallel to the current direction (Nakawo and Sinha, 1984; Langhorne and Robinson, 1986), therefore increasing the value of $a_{0}$, while in other locations the flow seems to inhibit maximum growth and scrves to decrease $a_{0}$.

\section{CONGLUSION}

The small-scale physical properties and structuralstratigraphic characteristics of five pairs of cores obtained from one site in the fast ice in McMurdo Sound were examined and the results were compared to previous studies. In addition, the first ice samples to be obtained from Pine Island Bay were characterizcd and compared to the McMurdo Sound cores and previous sea-ice research. Relatively cold annual air temperatures at PIB may prevent significant amounts of brine drainage, resulting in large vertical variations in temperature and salinity with cold, saline upper layers and warm lesssaline lower layers. Turbulent conditions during icc growth, perhaps the result of severe winter storms in the Pine Island Bay region, may lead to the non-uniform stratigraphy profiles characterized by large amounts of frazil ice and layers of tipped congelation ice. Warmer summer air temperatures at MCM create conditions which enhance brine drainage and result in salinity and temperature profiles that vary little with depth. Initial calm ice-growth conditions result in an upper congclation-ice layer, while supercooled water flowing out from the Ross Ice Shelf forms large, angular ice crystals which accrete on to the basc of the ice sheet, forming a lower layer of platelet ice. Due to the different physical environments of McMurdo Sound and Pine Island Bay, sea-ice characteristics differ betwen the sites and are more variable along the transect at $\mathrm{PIB}$ than MCM

\section{ACKNOWLEDGEMENTS}

This work was supported by U.S. National Science Foundation grant DPP-8915863. We reccived technical support and assistance from the officers and crew of the icebreaker USCGC Polar Sea and the U.S. Coast Guard aviation department.

\section{REFERENGES}

Cox, G.F. N. and W. F. Weeks. 1974. Salinity variations in sea ice. f Glaciol., 13 67$), 109-120$.

Crocker, G.B. and P. Wadhams. 1989. Modeling Antarctic fast-ice growth. 7. Glaciol., 35(119;, 3-8.
Danielson, A.L. and M.O. Jeffries. 1992. Small scale variability of physical properties and structural characteristics of a single ice floc Antart. J. U.S., 27 45$), 85-87$.

Eicken. H., M. A. Lange and G.S. Dieckmann. 1991, Spatial variability of sea-ice properties in the northwestern Weddcll Sea. 7. Geophrs. Res., 96(C6), 10,6013-10),615.

Gow, A.J.S., S.F. Acklcy, W.F. Weeks and J. W. Goroni. 1982 Physical and structural characteristics of Antarctic sea ice. Amn. Glaciol., 3, 113117.

Jcffries, M.O. and W. F. Weeks. 1991 a. Fast-ice properties and structure in McMurdo Sound. Antarcl. 7. U.S., 26(3), 94-95.

Jeffries, M.O. and W. F. Weeks. $1991 \mathrm{~b}$. Summer park-ice properties and structure in the western Ross Sca. Antard. 7. L.S., 26 5 , 95-97.

Jeffries, M.O. and W.F. Weeks, 1993. Structural characteristics and development of sea ice in the western Ross Sea. Antarctic. Sci., 5 1?, $63-75$.

Jeffrics, M. O., W. F. Weeks, R. Shaw and K. Morris. 1993. Structural characteristics of congelation and platelet ice and their role in the development of Antarctic land-fast sea ice. J. Glaciol, 39 132), 223-238.

Jeffries, M. O.. A.L. Veazer, K. Morris and H. R. Krouse. 1994a Depositional cnvironment of the snuw cover on West Antarctic packice floes. Ann. Glaciol, 20 (see paper in this volume?.

Jeffries, M. O.. R. A. Shaw. K. Morris, A. L. Veazey and H. R. Krouse. 1994b. Crystal structure, stable isotopes $\left\{\delta^{18} \mathrm{O}\right)$ and development of sea ice in the Ross, Amundsen and Bellingshausen Seas, Antarctica. 7. Ceophys. Res, $99(\mathrm{C} 1), 985995$.

Lake, R.A. and E.L. Lewis. 1970. Salt rejortion by sea ire during growth. 7. Geophys. Res., 75 (3), 583-597.

Lange, M.A. and H. Eicken. 1991. Textural characteristics of sea ice and the major mechanisms of ice growth in the Weddcll Sca. Am Glaciol.. 15. 210-215.

Langhorne, P.J. 1983. Laboratory experiments on crystal orientation in $\mathrm{NaCl}$ ice. Ann. Glaciol., 4, $163-169$.

Langhorne, P.J. and W. H. Robinson. 1986. Alignment of crystals in seat ice due to lluid motion. Cold Reg. Sci. Technol, 12 2), 197-214.

Leventer, A, R.B. Dunbar, M. R. Allen and R. Y. Wayper. 1987. Ice thickness in McMurdo Sound. Antart. J. L.S., 22 5), 94-96.

Lewis, E.L. and R.G. Perkin. 1985. The winter oceanography of McMurdo Sound, Antarctica. In Jacobs, S. S., ed. Ocemolog' of the Antartic continental shelf. Washington, DC, American Geophysical Lnion, ]45-165. Antarctic Research Serics 43.)

Iofgren, G. and W.F. Weeks. 1969. Fffect of growth parameters on substructure spacing in $\mathrm{NaCl}$ ice crystals. 7. Glaciol, 8 ; $52,153-164$.

Nakawo, M. and N.K. Sinha. 1984. A note on brinc layer spacing in first-year sca icc. Amosphere-Ocean, 22 2), 193-206.

Paige, R.A. 1966. Crystallographic studies of sea ice in McMurdo Sound, Antärctica. U.S. Sav. Cir. Eng. Lab. Terhnic. Rep. R-494.

Paigs, R.A. and C.W. Lee. 1967. Preliminary studies on sea ice in McMurdo Sound, Antarctica, during "Decp Freeze 65". 7. Glaciol., 6 46), 515528.

Tucker, W.B., A.J. Gow and J.A. Richter. 1984. On small-seale horizontal variations of salinity in first-year sea ice. 7 . Geophlys. Res. 89(C1), $650 j-6514$.

Weeks, W.F. and A.J. Gow 1978. Preferred crystal orientations in the fast ice along the margins of the Arctic Occan. $\vec{J}$. Gerphys. Res., 83(C:10), 5105-5121.

Weeks, W.F. and A.J. Gow, 1980. Crystal alignments in the fast ice of aretic Alaska. 7. Geophys. Res., 85(C2), 1137-1146.

Wocks, W.F. and O.S. Lee. 1958. Observations on the physical properties of sea-ice at Hopedale, Labrador, Arctic. 11, 134155.

Weeks, W. F. and O.S. Lee. 1962. The salinity distribution of young seaice. Arctic, 15, 92-108.

Zwally, H.J., J. C. Comiso, C. L. Parkinson, W.J. Campbell, F. D. Carsey and P. Gloersen. 1983. Antartic sea ice. 1973 1976: satellite passize-microwate obremations. Washington, D)C, National Acronautics and Space Administration. (NASA SP-459.)

The accuracy of references in the lext and in this list is the responsibility of the authors, to whom queries should be addressed. 